\title{
Developing ethics competencies among science students at the University of Copenhagen
}

\author{
T. Børsen* \\ Center for the Philosophy of Nature and Science Studies, University of Copenhagen, \\ Copenhagen, Denmark
}

(Received 2 August 2007; final version received 12 February 2008)

\begin{abstract}
Many philosophers and sociologists of science have tried to understand the profound changes that have occurred in science, engineering and technology. In the first part of this paper, I present the work of one such scholar: Jerome Ravetz who, in collaboration with Silvio Funtowicz, has characterised what he calls 'postnormal science'. The purpose of this theoretical part of the paper is to describe what characterises contemporary science and to formulate which competencies contemporary scientists need to act ethically. In the second part of the paper, I present and analyse the course 'Philosophy of Science and Ethics' that I have taught since 2005 to biochemistry, chemistry and nanotechnology students at the University of Copenhagen. The course is intended to prepare its participants for postnormal knowledge production that is scientific work that is embedded in a societal context characterised by uncertainty and conflicting values systems. With this in mind, I analyse the course by relating its content to the concepts that describe postnormal science, and I discuss how the course develops the ethics competencies that contemporary scientists need to work in postnormal science. I will also briefly discuss the relevance of the course for engineering students.
\end{abstract}

Keywords: University Science Education; Case-based Teaching; Philosophy of Science and Ethics Teaching; Ethics Competencies; Technoscience; Postnormal Science

Science and engineering graduates can no longer expect a conventional university career with tenure. Neither is it likely that they will remain in the same job at a private business, in a government office or at a local authority for a long period of time.

The jobs they hold will probably be project oriented, and their projects time-limited and involve many different partners representing an array of institutions. If they do research in the public sector, their research projects might very well be co-sponsored externally.

Local research quality criteria have emerged, as science and engineering projects are expected to be useful to stakeholders. Today an array of actors invests cultural and financial capital in research projects, which in return are expected to produce returns. The societal and political context influences the questions taken up by scientists and engineers.

Main-stream research projects used to be 'normal'; scientists and engineers were expected to produce clear-cut answers to the questions they investigated. Certainty expectations defined, or at least heavily influenced, what kind of research questions scientists chose to scrutinise and the

*Email: borsen@nbi.dk

ISSN 0304-3797 print/ISSN 1469-5898 online

(C) 2008 SEFI

DOI: $10.1080 / 03043790801987735$

http://www.informaworld.com 
problems engineers tried to solve. Only puzzles and problems that could be solved with certainty would be labelled 'scientific' and judged worthy of investigation (Hansen 2006).

The term 'normal science' is taken from Kuhn (1962). According to Kuhn, normal science is the most predominant form of academic science; it deals with puzzle-solving in contrast to revolutionary science, another form of academic science, that aims at the development of new theories and reinterpretations of scientific concepts. Normally, scientists compete in solving the puzzles defined by the disciplinary matrix under which they work, rather than in developing radical new scientific ideas. In this article, the term 'normal science' is used in a broader sense, as it is used to refer to standard uses of scientific theories and methods within both the academic and applied sciences.

Stakeholders' utility expectations today often outdo conventional certainty expectations. Questions that stakeholders find important cannot, necessarily, be answered with clear-cut certainty. It is difficult for normal scientific and engineering projects to flourish in a context characterised by stakeholder involvement and uncertainty. Hence, the future career prospects for science and engineering students are today qualitatively different from those prevailing some 30 years ago. Today the scientific and technological landscape is conflict-ridden, as tensions between different expectations easily collide in the realm of science and engineering, e.g. certainty versus utility.

In the remaining part of this paper, I first introduce the concept of postnormal science, which I claim characterises modern scientific research. Then I present and analyse the course 'Philosophy of Science and Ethics' that is taught to biochemistry, chemistry and nanotechnology students at the University of Copenhagen.

\section{Postnormal science}

In his new book, The No-Nonsense Guide to Science (2006), Ravetz distinguishes between a number of scientific practices, all with reference to two parameters: the degree of certainty with which the questions posed can be answered, i.e. system uncertainties, and the amount of cultural and financial capital invested in research questions, i.e. decision stakes. ${ }^{1}$ Here I reduce Ravetz' categories of scientific activity into only two qualitatively different kinds: normal and postnormal science.

Normal scientists, regardless of whether they work at a university or in industrial research laboratories, basically solve puzzles, either purely scientific ones or puzzles related to standard industrial applications. Normal scientific questions have one, and only one, solution, and hence are characterised by little uncertainty. If a scientist fails to solve a normal scientific puzzle, it is usually only the individual scientist's reputation or job that is at stake. Normal science only focuses on how to solve puzzles and problems in the most efficient way; it does not reflect on why it is important to solve particular solvable puzzles and problems.

Postnormal science is characterised by a high degree of system uncertainty and/or high decision stakes. Whether or not GM foodstuff is dangerous to human health is a postnormal question for two reasons: one, because the question cannot be answered with certainty, presently we neither have the knowledge nor the methods to give clear-cut answers to such questions; two, the private industry, local farmers, grassroots organisations, governmental agencies and others have invested a lot of money as well as their reputations among partners, in the media etc., in attempts to decide the question in a certain way. It may also be that future profits, benefits or risks are at stake. The answers that are desired by different stakeholders differ. This is what puts postnormal scientists under strain and leads to specific ethical issues. Postnormal themes are usually political, and hence they often encompass political advice on controversial issues. Postnormal science is not just instrumental, it also reflects on the desired outcome. Hence, we can now define postnormal science in terms of high uncertainty of outcomes and/or high stakeholder involvement. 
The characterisation of postnormal issues might change over time: suspicion of a potential threat towards human health usually emerges when the uncertainties are high and the decision stakes low, but as knowledge and attention over time increase, the threat might best fit with a situation where both uncertainties and decision stakes are high, or maybe even in a situation where the uncertainties are low, but the decision stakes remain high. A postnormal issue may also turn normal, where both uncertainties and decision stakes are low, if new scientific methods and knowledge are generated so that uncertainties are reduced at the same time as consensus is achieved among involved parties on how to handle the issue.

According to the postnormal account, the contemporary science environment is like a battlefield where special interests, financial, political, institutional, etc., are in combat using the results of scientific research as weapons. A combatant supports the production of new scientific insight and rejects, publicly doubts, reinterprets or puts emphasis on parts of the existing knowledge corpus, to promote his or her case. This may clearly pose ethical questions to the individual scientist. Which competencies does he or she need to act ethically in such an environment?

To formulate some of the competencies that scientists need to perform ethically in postnormal research, I will mention the ability to identify postnormal issues, to portray involved actors value systems and underlying assumptions fairly, to synthesise/accept a compromise among the different views involved and to react consciously if asked for involvement in projects that he or she finds conflicts with his or her ethical orientation system. I am fully aware that these are difficult issues. ${ }^{2}$ Nevertheless, as postnormal science captures important traits of contemporary science, students need to be prepared for dealing with postnormal issues. I will now turn to a description of a course that is aimed at helping future scientists deal with such issues.

\section{Teaching philosophy of science and ethics to science students at the University of Copenhagen}

Since the spring of 2005, I have been managing and teaching the course 'Philosophy of Science and Ethics' to third-year biochemistry, chemistry and nanotechnology students at the Faculty of Science, University of Copenhagen. ${ }^{3}$ The course is compulsory, with a weighting of 7.5 ECTS points and is taught twice a year to increase the flexibility. It is the only compulsory course in the curriculum that asks the students to reflect on their discipline. Approximately 100 students per year attend the course.

The goal of the course is to help the students to see their scientific discipline in a wider context and to enable them to analyse postnormal problems. The course is case-based: concrete events/problems are analysed, by linking them to sociological, historical, philosophical or ethical theories. An important trait of the course is that one of its intentions is to show how ethical aspects of science and technology are intertwined with epistemological issues. This interrelatedness arises because of the circumstance that scientific analysis, risk assessment and personal involvement are all necessary to understand and handle the postnormal problems.

The teaching period is 7 weeks followed by an oral exam. One week in total is allocated for introducing and closing/evaluating the course. During the remaining 6 weeks, one case per week is addressed. In each case, a concrete problem is presented. The problems are approached as perceived by concrete actors. Based on the thorough course evaluations that are always carried out when a course ends, and on the students' performance at their oral exams, it is my impression that a concrete focus helps the students to relate to the course content, which is very different from their other courses in the biochemistry, chemistry and nanotechnology study programmes. ${ }^{4}$

In addition to a description of a series of events, each case includes texts that address philosophical, sociological or ethical theories, central concepts, which the students are asked to affiliate to 
the series of events. To help connect the concrete events to the central concepts, a list of questions is included in each case.

Each case is presented by a group of students to the rest of the class. The students, who are not presenting a case in a given week, act as opponents/reviewers of different aspects of the case presentation. Some days before each student presentation, the central concepts, philosophical, sociological, ethical theories, that are relevant to the case are introduced in conventional lectures. The lecture sessions are immediately followed by $2 \mathrm{~h}$ of class work, where the students discuss the central concepts presented earlier that day and prepare themselves for their presentation/review a few days later.

To pass the course, the student must pass an individual oral exam. At the exam, the student draws one of the six cases dealt with during the course and is then examined on that case. The students are also expected to be able to identify relations between the six cases. Before a student is qualified to enter the oral exam, a group report, written on the basis of the case presentation and received feedback from fellow students and the teacher, must be approved.

\section{Course content: descriptions of the six cases}

The first case included in the fall 2007 version of the course addresses Jan Hendrik Schön's experiences. Schön was a young promising nano researcher who was found guilty of scientific misconduct. After Schön began working at Bell Labs, he published intensively in high-ranking journals. An anonymous tip from one of Schön's co-workers at Bell Labs draw physicist Lydia Sohn's attention to the fact that Schön had used identical figures in different papers. More suspicious details piled up, and in 2002, Bell Labs set up a committee to investigate the accusations against Schön. The committee found Schön guilty of scientific fraud in 16 out of 24 charges (Beazley et al. 2002).

The students are asked to analyse the Schön story using Merton's 'The ethos of science' - i.e. the CUDOS set of norms: especially the norms 'universality', which states that scientific results must be tested against universal quality criteria, e.g. new knowledge must be empirically grounded and not contradict known theories, observations must be replicable, and 'organised scepticism' that commits members of scientific communities not only to produce new scientific results, but also to test the claims of their peers and others (Merton 1973).

Different countries' definitions of and legislation on scientific dishonesty are presented. The processes leading to the latest revision of the Danish Executive Order on the Danish Committees on Scientific Dishonesty are portrayed. The analytical perspective of this case is: Do the mechanisms and institutions of science manage to weed out scientific fraud?

The second case deals with the events leading up to the discovery of the DNA structure that earned James Watson, Francis Crick and Maurice Wilkins the Nobel Prize in 1963. Two different accounts of the series of events are presented: an extract of Watson's autobiography (1968), where he describes his personal perception of the events leading up to the discovery of DNA's structure, which contains an unflattering characterisation of Rosalind Franklin, and parts of Sayre's (1975) Franklin biography, where she tries to show that Watson's characterisation of Rosalind Franklin is fictitious.

The key issue in the second case is whether Rosalind Franklin deserves substantial credit for the discovery of the structure of the DNA. Merton's ethos of science can be used in the analysis of this question, especially the norm 'disinterestedness' that states that researchers should not be rewarded for achieving pre-formulated conclusions, instead they are according to Merton motivated to do research as they strive for the recognition of their peers. This turns scientific work 
into a competition, where the winner takes all. The students are asked whether they think Watson and Crick respected Merton's norms.

Two additional analytical tools are presented to cast light upon the events leading up to the discovery of the structure of the DNA double-helix: different scientific methods are introduced, the empirico-inductive, hypothetico-deductive and abductive-explanatory methods, along with the hypothesis that Watson and Franklin held different methodological views preventing them from recognising each others contributions. The question regarding Franklin's importance for the discovery of the structure of DNA can also be seen as an example of discrimination. Hence, feminist philosophy of science is presented as an additional analytical tool.

The first two cases present the normal scientific events. The purpose is to teach the students the internal ethics of science and to reflect on it. This is important for the following four cases. They address series of events that can be characterised as belonging to postnormal research. It is important to present and discuss the internal ethics of science, and its institutions, as it is used by researchers in a postnormal environment, though interpretations of the values are disputed and system uncertainties are high.

The third series of events, analysed in the course, is the controversy of cold fusion. In 1989, two chemists (Pons and Fleishmann) claimed at a press conference that they had observed cold fusion using low-tech electro-chemistry equipment. Just after the press conference, a number confirmations of their revolutionary result were reported, but as time went by physicists especially criticised Pons and Fleishmann's claimed observation of cold fusion. It was stated that cold fusion contradicted well-established physical knowledge, and reports of unsuccessful attempts to reproduce their experiments began to pile. In 1990, Nature proclaimed that cold fusion had not been found (vol. 344, p. 365). The different portraits of the controversy included in the case are written by Collins and Pinch (1994), Rousseau (1992) and Gieryn (1992).

The students are asked to base their analysis of the controversy of cold fusion on accounts of the role that experiments play in science. The presentation of the empirico-inductive and hypotheticodeductive methods from case two can be drawn in, as can Hacking's (1983) account of the role experiments in science, Collins' experimenter's regress (1985) and pathological science (Rousseau 1992), which are included as potential analytical tools.

Prejudice in science can also be used as an analytical theme (chemistry versus physics, and pure versus applied science). So can the roles of patents, utility-oriented quality criteria, which are excluded from CUDOS, and the media in science.

The cold fusion case is in a boundary area between normal and postnormal science: most students approach it as a case of normal science, as the reported phenomenon is widely rejected today, though the US military allegedly continues to fund related scientific projects. Neither is cold fusion on the political agenda, though high stakes are embedded in the public/political debate on future energy sources. In this case, the students begin to see that scientific work can be analysed from both a normal and a postnormal perspective. The ability to distinguish between normal and postnormal science is a theme in the following three cases.

The fourth case addresses the experiences of Ignacio Chapela, a researcher at UC Berkeley. In 1998, Berkeley's Biosciences Department made a 5-year agreement with the agro-company Novartis (that later change name to Syngenta): the company would support the department with $\$ 25$ million and in return gain two seats out of five on its research board plus the right to licence one-third of the discoveries done by researchers at the department. The agreement was criticised by staff and student representatives; among those are the ecologist Ignacio Chapela and his Ph.D. student David Quist, founding member of the organisation 'Students for Responsible Research'.

In 2001, Chapela and Quist published a paper in Nature that concluded that native Mexican maize was polluted with sequences from GM-maize produced by Novartis and other companies. Nature received a number of critical letters from researchers, many with present or prior affiliation with the Berkeley's Biosciences Department, arguing that Chapela and Quist's conclusions were 
unfounded. The editors of Nature decided to publish a statement saying that the evidence available was not sufficient to justify the publication of the original paper. The journal did not withdraw the paper, but published two critical letters plus Chapela and Quist's reply to the criticism. This was done so that the 'readers [could] judge the science for themselves' (Nature, vol. 416, p. 600).

Chapela's experiences can be viewed as an example of scientific work that did not follow good scientific practice. However, at least two additional analytical perspectives can be applied: one is Ziman's (2000) account of post-academic science that states that university scientists follow both Merton's norms and the norms of industrial science. As the two sets of norms point in different directions, e.g.: Should a scientist present unbiased facts or stay loyal to the institution that pays his or her salary? This might well cause the individual researchers to have to cope with unpleasant situations. The students are asked to discuss which of the two set of norms scientists should obey.

The concept of junk science is introduced in this case. Junk science denotes attempts to undermine researchers' credibility driven by political, ideological, financial and other unscientific motives.

The fifth case tells the story of the German chemist Fritz Haber's involvement in the German chemical weapons programme during the First World War. (Postnormal science is not completely new). Two of the texts included in this case are taken from two newer Fritz Haber biographies that present different views on Haber's involvement in the development of chemical weapons (Stoltzenberg 2004, Charles 2005). During World War I German science in general, and the work of Haber especially, represents a marriage between science and warfare (Charles 2005: 177). Is this close relationship morally justifiable?

The students are asked to portray Haber's ethical orientation system by listing how he justified his involvement in the development of chemical weapons, and then to characterise it as 'utilitarian', 'deontological', 'virtuous', 'discursive' or as a mix of these theoretical directions. These ethical theories are introduced prior to the case work. Different understandings of the 'social and moral responsibility of scientists' are presented, and a number of examples of scientists who have acted accordingly are mentioned (Rotblat, Vanunu, etc.)

In the last case, the students are asked to imagine that they themselves are active researchers in a controversial scientific area and to reflect on whether they think ethical considerations are important for them. Having worked with the first five cases, the students ought to possess knowledge on where, when and how science is done today. Additional texts addressing different aspects of a techno-scientific conundrum, such as the toxicity of nano-particles or technical enhancement of human traits, are provided as resources for the construction of the fictitious researchers' reflections.

The students explicitly need to define how they understand ethics. Here they can draw in the ethical theories and the understandings of social responsibilities of the scientists presented in the Fritz Haber case. The text corpus of the last case also contains literature on legal regimes regulating certain kinds of technologies. These texts might be incorporated in or related to the student's understanding of ethics.

The last three cases address scientists' work that is embedded in a societal context characterised by uncertainty and conflicting values systems. The intention is to teach the students to paraphrase different perceptions of the series of events. Furthermore, the course participants are asked explicitly to formulate their own moral orientation systems and to evaluate the name of other scientists according to this criterion.

\section{Conclusion}

All of the cases included in the course 'Philosophy of Science and Ethics' deal with controversies, and the perspectives of involved parties are described. Hence, the course promotes the ability 
to recognise, analyse and understand the background/context of such controversies. Another common denominator of all six cases is that abstract theory is contextualised and used analytically in concrete events. This promotes the power to use abstract theories in concrete situations.

Some of the cases are portrayed as normal scientific incidents, and other cases are presented as postnormal. The course is intended to teach the students to distinguish between normal and postnormal science and to choose analytical tools accordingly. One final competency that is nurtured by the course is the capacity to formulate explicitly and use one's ethical orientation system.

All four competencies mentioned above are compatible with the needed ethics competencies outlined in the section on postnormal science, i.e. the ability to identify postnormal questions, fairly portray the involved actors' value systems and underlying assumptions, to synthesise/accept a compromise among these different views and to react consciously when asked to work on projects that come into conflict with the individuals' ethical orientation system.

We see that the first, second and fourth postnormal ethics competency are explicitly addressed in the course. However the third ethics competency is not. The students will have to learn to formulate/accept compromises among different stakeholders in a postnormal scientific controversy later as they progress in their professions. Some might add that this is unsatisfactory as students might justly expect that they will learn at the university how to deal with such issues. For now, I will leave the point to the future and only state that it is a challenging question both for teaching and for research.

In this paper, I have not addressed the question of teaching ethics to engineering students - only to science students. However, most engineering study programmes within the areas of chemical, bio-, and nanotechnology do not significantly differ from their counterparts taught at faculties of science, and it can be assumed that the graduates from these programmes are going to have similar jobs and hence will be confronted with similar phenomena. I expect that many of the cases and central concepts of the course are relevant for at least part of the study programmes in technical universities. In other words, the case-based approach to ethics teaching, presented in this paper, can be a strong source of inspiration when new ethics courses for chemical, bioand nanotechnology engineering students are developed. Some of the cases from the course 'Philosophy of Science and Ethics' for biochemistry, chemistry and nanotechnology students at the University of Copenhagen might also be used in ethics courses for engineering students, whereas other cases can be substituted with the new ones taken explicitly from the world of engineering.

\section{Notes}

1. The work of many more scholars could have been included in this paper: Lyotard (1984) and the concept of technoscience, Ziman (2000) and his definition of post-academic science, mode 2 production of knowledge as formulated by Helga Nowotny, John Gibbons and others (e.g. Gibbons et al. 1994, Nowotny et al. 2001), entrepreneurial science as proposed by Etzkowitz and others (e.g. Etzkowitz 2002, Etzkowitz and Leydesdorff 2000), Fuller (2000) and his idea of knowledge management based on the idea of social epistemology and Andrew Jamison and his concepts of hubris and hybrid imagination (e.g. Hård and Jamison 2005). The limited length of this paper restricts me to outlining the postnormal science framework only.

2. For instance, how does one react with respect to conscience if one is required to work on a project that one considers morally tainted? Some will say that the individual scientist is obliged to consciously object to such involvement, and hence face the possible repercussions. Others argue that this response is too individualistic and that approaches that involve structural changes or political actions are called for.

3. The Danish title of the course is 'Videnskabsteori og Etik'. The word 'etik' translates into 'ethics', 'videnskabsteori' has no direct English translation. In this paper, I translate 'videnskabsteori' into 'philosophy of science', though this is a too narrow concept, as 'videnskabsteori' in addition to philosophy of science also encompasses history and sociology of science; the German translation of 'videnskabsteori' is 'Wissenschaftstheorie'.

4. See (Hansen 2003, 2005) for a description and analysis of the chemistry study programme at the University of Copenhagen. 


\section{References}

Beazley, M.R. et al., 2002. Report of the investigation committee on the possibility of scientific misconduct in the work of Hendrik Schön and coauthors. Lucent Technologies. Available from: http://publish.aps.org/reports/lucentrep.pdf [cited 16 August 2007].

Charles, D., 2005. Between genius and genocide: the tragedy of FritzHaber, the father of chemical weapons. London: Jonathan Cape.

Collins, H., 1985. Changing order: replication and induction in scientific practice. London: Sage Publications.

Collins, H. and Pinch, T., 1994. The sun in a test tube the story of cold fusion. The Golem - what everyone should know about science. Cambridge: Cambridge University Press.

Etzkowitz, H., 2002. MIT and the rise of entrepreneurial science. London: Routledge Press.

Etzkowitz, H. and Leydesdorff, L., 2000. The dynamics of innovation: from national systems and 'mode 2' to a triple helix of university-industry-government relations. Research Policy, 29, 109-123.

Fuller, S., 2000. The governance of science: ideology and the future of the open society. Buckingham: Open University Press.

Gibbons, M. et al., 1994. The new production of knowledge: the dynamics of science and research in contemporary societies. London: Sage.

Gieryn, T.F., 1992. The ballad of Pons and Fleischmann: experiment and narrative in the (un)making of cold fusion. In: Ernan McMullin, ed. The social dimensions of science. South Bend: Notre Dame University Press, 217-243.

Hacking, I., 1983. Representing and intervening: introductory topics in the philosophy of natural science. London: Cambridge University Press.

Hansen, T.B., 2003. Between 'formation' [i.e. Bildung] and paradigm socialisation - draft to a theory of 'formation' relevant to chemistry-related university curricula and study programs (in Danish). PhD. Department of Medicinal Chemistry, Danish University of Pharmaceutical Sciences \& Centre for Educational Development in University Science, Aalborg University.

Hansen, T.B., 2005. Bildung and university science education. INES Newsletter, 48.

Hansen, T.B., 2006. Scientific bildung for the post-normal epoch. In: L.B. Henriksen, ed. Engineering science, skills and bildung, Aalborg: Aalborg University Press.

Hård, M. and Jamison, A., 2005. Hubris and hybrids: a cultural history of technology and science. New York: Routledge.

Kuhn, T., 1962. The structure of scientific revolutions. Chicago: University of Chicago Press.

Lyotard, J.-F., 1984. The postmodern condition: a report on knowledge. Manchester: Manchester University Press, 1984.

Merton, R.K., 1973. The normative structure of science. The sociology of science. Theoretical and empirical investigations. Chicago and London: University of Chicago Press, 1973.

Nowotny, H. et al., 2001. Re-Thinking Science: Knowledge and the Public in an Age of Uncertainty. London: Polity Press.

Ravetz, J., 2006. The No-Nonsense Guide to Science. London: New Internationalist Books.

Rousseau, D.L., 1992. Case studies in pathological science. American Scientist, 80, 54-63.

Sayre, A., 1975. Rosalind Franklin and DNA. New York: Norton.

Stoltzenberg, D., 2004. Fritz Haber: chemist, nobel laurate, German, Jew. Philadelphia, Pennsylvania: Chemical Heritage Press.

Watson, J., 1968. The double helix: a personal account of the discovery of the structure of DNA. New York: Atheneum.

Ziman, J., 2000. Real science: what it is and what it means. Cambridge: Cambridge University Press.

\section{About the author}

Tom Børsen (1970) holds an MSc in Chemistry and a PhD in University Science Education. He is an External Lecturer both at Center for the Philosophy of Nature and Science Studies, University of Copenhagen, and at the Department of Development and Planning, Aalborg University, where he teaches philosophy of science and engineering, science and technology studies and ethics to undergraduate and graduate science and engineering students. Dr Børsen is the Director of International Network of Engineers and Scientists' Projects on Ethics (http://www.inespe.org). His research is currently directed towards clarifying the idea of 'the socially responsible technoscientific expert'. 
Copyright of European Journal of Engineering Education is the property of Taylor \& Francis Ltd and its content may not be copied or emailed to multiple sites or posted to a listserv without the copyright holder's express written permission. However, users may print, download, or email articles for individual use. 